\title{
43. MÖSSBAUER CHARACTERIZATION OF SEDIMENTS FROM SITES 798 AND 799, JAPAN SEA ${ }^{1}$
}

\author{
Yoshitaka Minai, ${ }^{2}$ Iori Kusudo, ${ }^{3}$ Ryo Matsumoto, ${ }^{4}$ Haruo Sato,${ }^{3}$ and Takeshi Tominaga ${ }^{2}$
}

\begin{abstract}
${ }^{57} \mathrm{Fe}$ Mössbauer spectra for 26 sediment and 6 carbonate concretion samples from Sites 798 and 799 were recorded at $293 \mathrm{~K}$. Most spectra were deconvolved to two quadrupole doublets without magnetic hyperfine structure. Typical Mössbauer parameters were: isomer shift (I.S.) $=0.34 \mathrm{~mm} / \mathrm{s}$ and quadrupole splitting (Q.S.) $=0.64 \mathrm{~mm} / \mathrm{s}$ for the paramagnetic $\mathrm{Fe}^{3+}$ component (partly, pyrite); I.S. $=1.13 \mathrm{~mm} / \mathrm{s}$ and Q.S. $=2.64 \mathrm{~mm} / \mathrm{s}$ for the high-spin $\mathrm{Fe}^{2+}$ component derived from iron-bearing aluminosilicates. A few spectra included other high-spin $\mathrm{Fe}^{2+}$ components ascribed to iron-bearing carbonate minerals (e.g., ferroan magnesite), according to the Mössbauer parameters for $\mathrm{Fe}^{2+}$ in the carbonate concretions. We present the distribution of iron among different chemical forms as a function of depth. These data might indicate changes of depositional and diagenetic conditions.
\end{abstract}

\section{INTRODUCTION}

The oxidation state of the transition metals in sediments is a measure of the oxidation-reduction conditions of sedimentation. ${ }^{57} \mathrm{Fe}$ Mössbauer spectroscopy is a technique for characterizing iron-bearing phases in geological substances (Bancroft, 1973). With this technique we can investigate the oxidation state, coordination number, spin state, magnetic properties, site symmetry, and lattice dynamics of iron in solids (e.g., Greenwood and Gibb, 1971). Earlier studies demonstrated the applicability of Mössbauer spectroscopy in the determination of site populations of $\mathrm{Fe}^{2+}$ in silicate minerals (Bancroft et al., 1967, 1968). Extensive studies of Mössbauer spectra for silicates have demonstrated that multiphase assemblages such as rocks and sediments can be characterized by this technique (e.g., Bancroft, 1973; Tominaga and Minai, 1984; Bowen and Weed, 1984). Mössbauer spectroscopy is well recognized as a useful tool for the determination of $\mathrm{Fe}^{3+} / \mathrm{Fe}^{2+}$ ratio (e.g., Minai and Tominaga, 1982) and semiquantitative determination of distribution of iron among different minerals and lattice sites.

Mössbauer spectroscopy also has been applied to characterize oceanic sediments. Herzenberg (1970) measured the Mössbauer spectra of a red clay and a metalliferous sediment. He reports a high-spin $\mathrm{Fe}^{2+}$, paramagnetic $\mathrm{Fe}^{3+}$, a weak component with magnetic hyperfine structure for the red clay, and an $\mathrm{Fe}^{3+}$ absorption with superparamagnetic relaxation (microcrystalline goethite) for the metalliferous sediment. Minai et al. (1981) recorded the Mössbauer spectra of 20 deep-sea sediment samples from the Pacific, and reported regional variations of the relative content of high-spin $\mathrm{Fe}^{2+}$ and paramagnetic $\mathrm{Fe}^{3+}$. The variation was explained by regional changes of the mixing ratios among terrigenous, biogenic, and hydrogenous components. Similar results were also reported by Thijs et al. (1981) based on the Mössbauer spectra of sediments and manganese nodules in the $\mathrm{Pa}$ cific. Mössbauer characterization was also reported for the sedimentary sequence from a Deep Sea Drilling Project hole (Minai et al., 1987). In this article we report the oxidation states of iron and probable nature of the iron-bearing components in the sediments from Sites 798 and 799, based on the Mössbauer spectra for sediments

'Pisciotto, K. A., Ingle, J. C., Jr., von Breymann, M. T., Barron, J., et al., 1992. Proc. ODP, Sci. Resuits, 127/128. Pt. 1: College Station, TX (Ocean Drilling Program).

${ }^{2}$ Department of Chemistry, Faculty of Science, University of Tokyo, Hongo, Tokyo 113, Japan.

${ }^{3}$ Department of Chemistry, Faculty of Science, Science University of Tokyo, Kagurazaka, Tokyo 162, Japan.

${ }^{4}$ Geological Institute, Faculty of Science, University of Tokyo, Hongo, Tokyo 113 , and carbonate concretions. The distribution of iron among the sedimentary phases also has been estimated from the spectra.

\section{SAMPLE DESCRIPTION}

Sediment samples were collected from Leg 128 Sites 798 and 799 (Table 1A). The samples were analyzed by neutron activation analysis and X-ray-fluorescence spectroscopy (Minai et al., this volume). Six carbonate concretions were also analyzed in this work (Table 1B). Some of the sediment samples also contained minor amounts of authigenic carbonates as noted in Table 1A. Geological descriptions of Sites 798 and 799 are discussed by Ingle, Suyehiro, von Breymann, et al. (1990), and summarized here. Site 798 (Fig. 1) is located at a small basin on top of the Oki Ridge. A 517.9-m-long sediment section of late early Pliocene to Holocene age was recovered from Hole $798 \mathrm{~B}\left(37^{\circ} 3.848^{\prime} \mathrm{N}\right.$, $134^{\circ} 79.961^{\prime} \mathrm{E}$ ) in a water depth of $911.1 \mathrm{~m}$. Pelagic-hemipelagic sediments were deposited at an average sedimentation rate of approximately $120 \mathrm{~m} / \mathrm{m}$.y. The sediment sequence was divided into three lithologic units: Unit I ( $0-220 \mathrm{~m}$ below seafloor (mbsf), latest Quaternary to latest Pliocene), Unit II (220-455 mbsf, late Pliocene), and Unit III (455$518 \mathrm{mbsf}$, late to late early Pliocene). Site 799 (Fig. 1) is located in the Kita-Yamato Trough (Hole 799A: $39^{\circ} 22.046^{\prime} \mathrm{N}, 133^{\circ} 86.685^{\prime} \mathrm{E}$; Hole 799B: $\left.39^{\circ} 22.048^{\prime} \mathrm{N}, 133^{\circ} 86.645^{\prime} \mathrm{E}\right)$. From Holes $799 \mathrm{~A}$ and 799B, a 1084.0-m-long sedimentary sequence (early Miocene to Holocene age) was obtained from a water depth of $2073 \mathrm{~m}$ (Hole 799A). The column was divided into five lithologic units: Unit I (0-170 mbsf, Quaternary to late Pliocene), Unit II (170-457 mbsf, late Pliocene to late Miocene), Unit III (457-800 mbsf, late to middle Miocene), Unit IV (800-1020 mbsf, middle to early Miocene), and Unit V (1020-1084 mbsf, early Miocene). The average sedimentation rate was about $70 \mathrm{~m} / \mathrm{m}$.y., although the rate varied from 15 to $175 \mathrm{~m} / \mathrm{m} . \mathrm{y}$. throughout the core.

\section{EXPERIMENTAL METHODS}

The samples were washed with deionized water to remove sea salt before air drying. The dried samples were moderately pulverized to minimize the possible oxidation of iron in air. The sample powder was loaded in a sample holder to record the ${ }^{57} \mathrm{Fe}$ Mössbauer spectrum. The spectrum was recorded against a $740-\mathrm{MBq}^{57} \mathrm{Co}(\mathrm{Rh})$ source with a conventional transmission geometry, using an Austin Science Associates S-600 Mössbauer spectrometer. Most of the measurements were carried out at $293 \mathrm{~K}$. The spectra at $78 \mathrm{~K}$ were also recorded for a few samples. The Mössbauer spectra were fitted by means of a nonlinear least-squares routine (originally developed by Duke and Gibb, 1967) with an NEC PC-9801 personal computer to calculate Mössbauer parameters of the corresponding iron components. Isomer 
Table 1. Samples analyzed by Mössbauer spectroscopy.

\begin{tabular}{|c|c|c|c|c|}
\hline \multicolumn{5}{|c|}{ A. Sediment samples } \\
\hline $\begin{array}{l}\text { Sample } \\
\text { no. }\end{array}$ & $\begin{array}{l}\text { Hole, core, section } \\
\text { (interval in } \mathrm{cm} \text { ) }\end{array}$ & $\begin{array}{l}\text { Depth } \\
\text { (mbsf) }\end{array}$ & Unit & $\begin{array}{l}\text { Authigenic } \\
\text { carbonate }^{b}\end{array}$ \\
\hline $8 A-1$ & $798 \mathrm{~A}-1 \mathrm{H}-4,86-88$ & 5.36 & I & \\
\hline $8 A-5$ & $798 \mathrm{~A}-5 \mathrm{H}-2,86-88$ & 39.06 & I & \\
\hline $8 B-33$ & $798 \mathrm{~B}-33 \mathrm{X}-2,90-92$ & 309.58 & II & \\
\hline $8 B-47$ & $798 \mathrm{~B}-47 \mathrm{X}-6,30-32$ & 447.43 & II & \\
\hline $9 A-1 A$ & 799 A-1H-1, 1-2 & 0.02 & I & \\
\hline $9 A-1 B$ & $799 \mathrm{~A}-1 \mathrm{H}-1,12-14$ & 0.13 & I & \\
\hline $9 A-1 C$ & $799 \mathrm{~A}-1 \mathrm{H}-1,16-18$ & 0.17 & I & \\
\hline $9 A-1 D$ & $799 \mathrm{~A}-\mathrm{IH}-\mathrm{I}, 40-42$ & 0.41 & I & \\
\hline $9 \mathrm{~A}-3^{\mathrm{a}}$ & $799 \mathrm{~A}-3 \mathrm{H}-4,41-43$ & 15.61 & I & \\
\hline $9 A-6$ & $799 \mathrm{~A}-6 \mathrm{H}-2,44-46$ & 41.44 & I & \\
\hline $9 A-9$ & $799 \mathrm{~A}-9 \mathrm{H}-2,133-135$ & 71.12 & I & Calcite \\
\hline $9 \mathrm{~A}-22$ & $799 \mathrm{~A}-22 \mathrm{X}-1,91-93$ & 194.71 & II & Rhodochrosite \\
\hline $9 A-27$ & $799 A-27 X-3,126-128$ & 245.66 & II & Rhodochrosite \\
\hline $9 \mathrm{~A}-30$ & $799 \mathrm{~A}-30 \mathrm{X}-2,40-42$ & 262.40 & II & \\
\hline $9 A-36$ & $799 \mathrm{~A}-36 \mathrm{X}-2,41-43$ & 318.81 & II & \\
\hline $9 A-38^{\mathrm{a}}$ & $799 \mathrm{~A}-38 \mathrm{X}-6,39-40$ & 344.09 & II & \\
\hline $9 A-42$ & $799 \mathrm{~A}-42 \mathrm{X}-4,40-42$ & 379.90 & II & Rhodochrosite \\
\hline $9 \mathrm{~B}-12^{\mathrm{a}}$ & $799 \mathrm{~B}-12 \mathrm{R}-1,125-127$ & 549.15 & III & \\
\hline $9 \mathrm{~B}-17^{\mathrm{a}}$ & 799B-17R-1, 93-95 & 597.23 & III & Rhodochrosite and magnesite \\
\hline $9 B-20-7^{a}$ & $799 \mathrm{~B}-20 \mathrm{R}-7,30-32$ & 634.50 & III & \\
\hline $9 B-24^{a}$ & $799 \mathrm{~B}-24 \mathrm{R}-3,114-116$ & 667.94 & III & \\
\hline 9B-29 & $799 \mathrm{~B}-29 \mathrm{R}-7,50-52$ & 721.30 & III & \\
\hline $9 \mathrm{~B}-41^{\mathrm{a}}$ & $799 \mathrm{~B}-41 \mathrm{R}-1,40-42$ & 827.50 & IV & \\
\hline $9 B-49$ & $799 \mathrm{~B}-49 \mathrm{R}-2,19-21$ & 905.89 & IV & \\
\hline 9B-53 & 799B-53R-1, $46-48$ & 943.06 & IV & \\
\hline $9 B-61^{a}$ & 799B-61R-2, 49-52 & 1021.79 & V & \\
\hline \multicolumn{5}{|c|}{ B. Carbonate concretion samples } \\
\hline $\begin{array}{l}\text { Sample } \\
\text { no. }\end{array}$ & $\begin{array}{l}\text { Hole, core, section } \\
\text { (interval in } \mathrm{cm} \text { ) }\end{array}$ & $\begin{array}{l}\text { Depth } \\
\text { (mbsf) }\end{array}$ & Unit & $\begin{array}{l}\text { Principal } \\
\text { carbonate }\end{array}$ \\
\hline $8 \mathrm{~A}-17$ & $798 \mathrm{~A}-17 \mathrm{X}-\mathrm{CC}, 17-33$ & 169.95 & I & Ankerite \\
\hline $9 \mathrm{~A}-17$ & $799 \mathrm{~A}-17 \mathrm{H}-4,111-113$ & 151.11 & I & Rhodochrosite \\
\hline $9 B-20-2$ & 799B-20R-2, 63-72 & 627.36 & III & Ferroan magnesite \\
\hline $9 B-20-6$ & 799B-20R-6, 127-134 & 633.97 & III & Ferroan magnesite \\
\hline $9 B-31$ & 799B-31R-1, 32-33 & 731.12 & III & Dolomite \\
\hline $9 B-48$ & 799B-48R-2, 87-95 & 896.97 & IV & Dolomite \\
\hline
\end{tabular}

apyrite was identified by X-ray diffraction.

Identified by $\mathrm{X}$-ray diffraction. Minor amounts of carbonate minerals not listed may be contained in the sediment samples.

shifts are reported as the relative velocity from the centroid of the sextet for iron foil at $293 \mathrm{~K}$.

Intensity and line width for each peak of a doublet were constrained equally when the spectrum was fitted. The relative peak area is nearly equal to the relative population of iron in each phase if recoilless fractions are identical among all of the iron species in the sample. Typical errors mathematically determined by best-fit calculation for the Mössbauer parameters are as follows: $0.01 \mathrm{~mm} / \mathrm{s}$ for isomer shift (I.S.); $0.01 \mathrm{~mm} / \mathrm{s}$ for quadrupole splitting (Q.S.); 0.02 $\mathrm{mm} / \mathrm{s}$ for line width; $1 \%$ for relative area.

Six 300-mg samples were partially dissolved with $10 \mathrm{~mL}$ of $0.3 \mathrm{M}$ citrate for $30 \mathrm{~min}$ to selectively remove geochemical phases in the sediments. In this experimental procedure, it is likely that carbonates and ferric-manganese hydroxides and oxyhydroxides were mostly dissolved. The Mössbauer spectra for the residues were also recorded after air drying at ambient temperature.

\section{RESULTS}

Representative Mössbauer spectra for the sediments from Site 799 are shown in Figure 2. The Mössbauer parameters calculated from the spectra for 26 sediment and 6 carbonate concretion samples are listed in Tables 2 and 3 , respectively. Two pairs of quadrupole doublets were observed in most of the spectra (Fig. 2). No traces of magnetic hyperfine structure were seen in any of the spectra recorded. The Mössbauer parameters for the residues remaining after partial dissolution are listed in Table 4, in addition to the relative absorption areas for the iron components before and after dissolution. Although the Mössbauer parameters (I.S. and Q.S.) after dissolution are identical with the previous parameters, the relative peak areas changed significantly after dissolution, particularly for those samples containing $\mathrm{Fe}^{2+}$ carbonates.

\section{DISCUSSION}

\section{Assignment of Mössbauer Absorptions}

The Mössbauer parameters of the quadrupole doublets (Table 2) for the sediments from Sites 798 and 799 were plotted in Fig. 3. We can assume at least three components in the spectra. Typical Mössbauer parameters for the spectral components are as follows: I.S. = $0.34 \mathrm{~mm} / \mathrm{s}$, Q.S. $=0.64 \mathrm{~mm} / \mathrm{s}($ doublet A);. .S. $=1.13 \mathrm{~mm} / \mathrm{s}$, Q.S.$=$ $2.64 \mathrm{~mm} / \mathrm{s}$ (doublet B); I.S. $=1.24 \mathrm{~mm} / \mathrm{s}$, Q.S. $=1.88 \mathrm{~mm} / \mathrm{s}$ (doublet C). The parameters for doublets A and B are typical for paramagnetic $\mathrm{Fe}^{3+}$ and six-coordinated high-spin $\mathrm{Fe}^{2+}$ components, respectively. None of the spectra, even at $78 \mathrm{~K}$, shows magnetic hyperfine structure. This implies that crystalline oxyhydroxides such as goethite can be excluded as the paramagnetic $\mathrm{Fe}^{3+}$ component corresponding to doublet A. However, the parameters for low-spin $\mathrm{Fe}$ (II) in pyrite (Morice et al., 1969) are also identical with those of doublet A. As shown in Table 1A, pyrite was identified in several sediment samples from Site 799. Absorption of pyrite overlaps the absorptions of paramagnetic $\mathrm{Fe}^{3+}$ at the position of doublet $\mathrm{A}$. Further deconvolution of doublet A in the Mössbauer spectra of the sediments is difficult because Mössbauer parameters at room temperature are almost identical among various $\mathrm{Fe}^{3+}$-bearing minerals and pyrite. The component (doublet A) for the sediments could be ascribed to ferric gel, pyrite, iron-manganese hydroxides and oxyhydroxides, and/or aluminosilicates. Because sediment, of course, is a mixture of various materials, it is possible that the observed absorptions correspond to overlapping signals from several of these ferric components and pyrite. The high-spin $\mathrm{Fe}^{2+}$ component (doublet $\mathrm{B}$ ), which is seen in most of the spectra, can be ascribed to $\mathrm{Fe}^{2+}$ in aluminosilicates based on its Mössbauer parameters. The relative peak area of doublet $B$ was about $30 \%$ for most of the sediments analyzed (Fig. 4).

In the spectra (e.g., Fig. 2D) from a few sediment samples (Samples 9B-12,9B-17, and 9B-20-7) doublet $\mathrm{C}$ is different in its parameters from doublets $\mathrm{A}$ and $\mathrm{B}$. The parameters for doublet $\mathrm{C}$ are identical to the parameters reported for iron-bearing carbonates in the literature (e.g., Minai et al., 1987, Mørup et al., 1985, Ono and Ito, 1964); this is consistent with the fact that the sediments recovered from Sites 798 and 799 contain various types of carbonate concretions (Matsumoto, this volume).

\section{Comparison of Sediment Mössbauer Parameters with those for Carbonate Concretion}

To confirm the assignment of the $\mathrm{Fe}^{2+}$ component (doublet $\mathrm{C}$ ), we recorded Mössbauer spectra of six carbonate concretion samples (Table 1B). The Mössbauer parameters for these samples are listed in Table 3. These samples may also contain various minerals other than carbonates and, therefore, part of the absorptions can be ascribed to noncarbonate minerals. The Mössbauer parameters for $\mathrm{Fe}^{2+}$ in the carbonate concretions are plotted in Figure 5. This figure also includes the parameters of doublets $\mathrm{B}$ and $\mathrm{C}$ for the sediment samples. The parameters for ankerite (Sample 8A-17), which rarely occurred at Sites 798 and 799, agree with reported values (I.S. $=1.21-1.30 \mathrm{~mm} / \mathrm{s}$ and Q.S. $=1.40-1.65 \mathrm{~mm} / \mathrm{s}$ ) for ankerite, ferroan dolomite, or $\mathrm{Fe}^{2+}$ in calcite (Mørup et al., 1985). The isomer shift and quadrupole splitting are slightly different from those of doublet $\mathrm{C}$ in the sediment samples (Fig. 5). The Mössbauer parameters for magnesite concretions (Samples 9B-20-2 and 9B-20-6) are nearly identical to those of the $\mathrm{Fe}^{2+}$ component (doublet $\mathrm{C}$ ) in the spectra for the sediment samples 9B-12, 9B-17, and 9B-20-7 (Table 2 and Fig. 5).

The Mössbauer spectra for the dolomite concretions (9B-31 and 9B-48) were also recorded. The Mössbauer parameters for 9B-31 


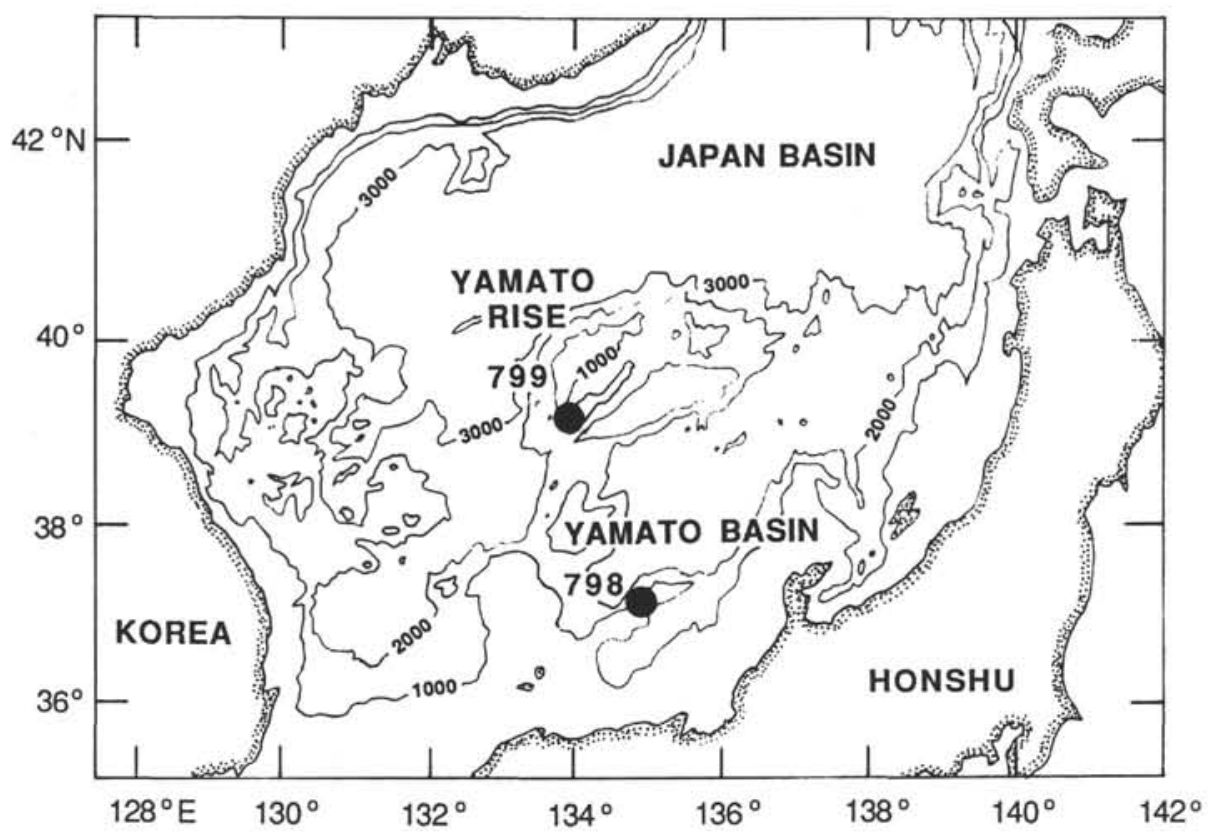

Figure 1. Locations of Leg 128 Sites 798 and 799.

(dolomite) are different from the other carbonates (Table 3 and Fig. 5): higher I.S. and lower Q.S., whereas the parameters for Sample 9B-48 (dolomite) are similar to those for Sample 8A-17 (ankerite). This discrepancy in the Mössbauer parameters may be due to the difference in $\mathrm{Fe}^{2+}$ content between the dolomite samples. It is noteworthy that the parameters for both dolomite samples differ from the parameters for the $\mathrm{Fe}^{2+}$ component presumably representing ironbearing carbonates in the sediment samples. The Mössbauer parameters for rhodochrosite (Sample 9A-17) are nearly identical with the parameters of doublet B ascribed to aluminosilicates. Because iron substitutes for about a few percent of manganese in the rhodochrosite concretions from Site 799 (Matsumoto, this volume), it is likely that the $\mathrm{Fe}^{2+}$ component in Sample 9A-17 (rhodochrosite concretion) is due to aluminosilicates.

The Mössbauer parameters for siderite are I.S. $=1.239 \mathrm{~mm} / \mathrm{s}$ and Q.S. $=1.798 \mathrm{~mm} / \mathrm{s}$ (Ono and Ito, 1964). These parameters also are similar to those of the $\mathrm{Fe}^{2+}$ in the sediment samples. However, X-ray diffraction and electron probe microanalysis (Matsumoto, this volume) indicate that the carbonate concretions from Site 799 are composed of rhodochrosite, calcite, ferroan magnesite (breunnerite), and dolomite-ankerite, whereas dolomite is predominant in the sediments from Site 798. These analyses suggest that siderite is a very rare authigenic carbonate in Sites 798 and 799 (Matsumoto, this volume). Presumably, doublet $\mathrm{C}$ in the spectra cannot be ascribed to siderite even though the parameters of doublet $\mathrm{C}$ are similar to those for this mineral.

Comparison of the Mössbauer parameters of the quadrupole doublets (doublet C) in the sediments (Samples 9B-12, 9B-17, and 9B-20-7) with those for carbonate concretions discussed previously, indicates that the carbonate $\mathrm{Fe}^{2+}$ component (doublet $\mathrm{C}$ ) can be attributed to $\mathrm{Fe}^{2+}$ in ferroan magnesite. Ankerite (Sample 8A-17) or ferroan dolomite (Mørup et al., 1985) are less likely to be the source of the $\mathrm{Fe}^{2+}$ carbonate component in the samples (Samples 9B-12, 9B-17, and 9B-20-7). Ankerite and ferroan dolomite occur frequently as carbonate concretions in Site 799 (Matsumoto, this volume). Specific carbonate minerals cannot be identified in the samples analyzed based solely on Mössbauer results. It is likely that sediments from other positions in the sediment sequence contain carbonates as iron-bearing phases. A component with small peak area (less than approximately $2 \%-3 \%$ ) could not be determined by the fitting routine used. Thus it is possible that small amounts of carbonates are contained in the sediment samples where the $\mathrm{Fe}^{2+}$ component ascribed to a carbonate phase could not be observed in the spectrum. It is also possible that the determined parameters may be intermediate between the two overlapping doublets, particularly if one doublet is much weaker than the other. As seen in Table 2 and Figure 5, the Mössbauer parameters of doublet B ascribed to aluminosilicates in some samples (enclosed with broken lines in Fig. 5) are somewhat different from the parameters in most of the samples. It is possible that in these cases a small fraction of iron could be contained in carbonate minerals.

\section{Partial Dissolution of Sediment Samples}

Changes of Mössbauer parameters and peak-area ratios after partial dissolution may provide a clue for identifying the $\mathrm{Fe}^{3+}$ and $\mathrm{Fe}^{2+}$ components. The Mössbauer parameters for the iron species after partial dissolution (Table 4) are similar to those obtained before the treatment with citric acid (Table 2). However, the relative peak areas of doublet A remained constant or increased after dissolution whereas the areas for the $\mathrm{Fe}^{2+}$ components (doublet $\mathrm{C}$ ) decreased (Table 4 and Fig. 6). This implies that most of the species corresponding to doublet $\mathrm{A}$ in the samples were not dissolved by this experimental treatment, whereas part of the carbonates in the sediments (Samples 9B-12, 9B-17, and 9B-20-7) were dissolved by the citric acid solution. Thus, perhaps doublet A cannot be ascribed to iron oxyhydroxides and hydroxides. The results are consistent with the absence of magnetic hyperfine structure in the spectra at $78 \mathrm{~K}$, indicating a small amount of the magnetically ordered $\mathrm{Fe}^{3+}$-phases. However, such a partial-dissolution experiment does not have the high efficiency and selectivity necessary to dissolve particular phases from multiassemblages. Efficiency and selectivity of partial dissolution depends highly on particle size, complexity of the assemblages, and other factors that can be difficult to control. Thus, the results in Table 4 are only qualitative.

\section{Comparison of Mössbauer Absorption Areas with Chemical Composition of the Sediment Samples Containing Carbonates}

As mentioned above, iron substitutes for a small percentage of manganese in the rhodochrosite concretions from Site 799 (Matsumoto, this volume). Manganese contents in the rhodochrosite-bearing 
Table 2. Mössbauer parameters and relative absorption areas for the sediment samples from Sites 798 and $\mathbf{7 9 9}$, derived from the spectra recorded at $293 \mathrm{~K}$.

\begin{tabular}{|c|c|c|c|c|c|}
\hline $\begin{array}{l}\text { Sample } \\
\text { no. }\end{array}$ & $\begin{array}{l}\text { Doublet } \\
\text { component }\end{array}$ & $\begin{array}{l}\text { Isomer } \\
\text { shift }^{\mathrm{a}} \\
(\mathrm{mm} / \mathrm{s})\end{array}$ & $\begin{array}{l}\text { Quadrupole } \\
\text { splitting } \\
(\mathrm{mm} / \mathrm{s})\end{array}$ & $\begin{array}{l}\text { Line } \\
\text { width } \\
(\mathrm{mm} / \mathrm{s})\end{array}$ & $\begin{array}{c}\text { Relative } \\
\text { area } \\
(\%)\end{array}$ \\
\hline \multirow[t]{2}{*}{$8 \mathrm{~A}-1$} & A & 0.34 & 0.66 & 0.58 & 69 \\
\hline & B & 1.13 & 2.62 & 0.47 & 31 \\
\hline \multirow[t]{2}{*}{$8 A-5$} & A & 0.32 & 0.68 & 0.65 & 71 \\
\hline & B & 1.12 & 2.63 & 0.48 & 29 \\
\hline \multirow[t]{2}{*}{$8 B-33$} & A & 0.38 & 0.83 & 0.72 & 78 \\
\hline & B & 1.16 & 2.66 & 0.43 & 22 \\
\hline \multirow[t]{2}{*}{$8 B-47$} & A & 0.35 & 0.71 & 0.68 & 88 \\
\hline & B & 1.13 & 2.67 & 0.34 & 12 \\
\hline \multirow[t]{2}{*}{$9 \mathrm{~A}-1 \mathrm{~A}$} & A & 0.37 & 0.63 & 0.65 & 73 \\
\hline & B & 1.15 & 2.67 & 0.39 & 27 \\
\hline \multirow[t]{2}{*}{$9 A-1 A^{b}$} & A & 0.46 & 0.63 & 0.67 & 74 \\
\hline & B & 1.24 & 2.86 & 0.39 & 26 \\
\hline \multirow[t]{2}{*}{$9 A-1 B$} & A & 0.37 & 0.62 & 0.65 & 74 \\
\hline & B & 1.12 & 2.63 & 0.35 & 25 \\
\hline \multirow[t]{2}{*}{$9 A-1 C$} & A & 0.37 & 0.60 & 0.63 & 74 \\
\hline & B & 1.12 & 2.63 & 0.34 & 26 \\
\hline \multirow[t]{2}{*}{$9 A-1 D$} & A & 0.36 & 0.55 & 0.68 & 72 \\
\hline & B & 1.13 & 2.64 & 0.36 & 28 \\
\hline \multirow[t]{2}{*}{$9 \mathrm{~A}-3$} & A & 0.33 & 0.64 & 0.44 & 70 \\
\hline & B & 1.13 & 2.63 & 0.40 & 30 \\
\hline \multirow[t]{2}{*}{$9 A-6$} & A & 0.34 & 0.62 & 0.50 & 70 \\
\hline & B & 1.13 & 2.61 & 0.38 & 30 \\
\hline \multirow[t]{2}{*}{$9 A-9$} & A & 0.34 & 0.67 & 0.45 & 78 \\
\hline & B & 1.15 & 2.53 & 0.47 & 22 \\
\hline \multirow[t]{2}{*}{$9 A-22$} & A & 0.35 & 0.63 & 0.63 & 7 \\
\hline & B & 1.16 & 2.69 & 0.41 & 29 \\
\hline \multirow[t]{2}{*}{$9 A-27^{c}$} & A & 0.31 & 0.63 & 0.64 & 75 \\
\hline & B & 1.17 & 2.65 & 0.37 & 25 \\
\hline \multirow[t]{2}{*}{$9 A-30$} & A & 0.35 & 0.66 & 0.58 & 74 \\
\hline & B & 1.16 & 2.69 & 0.36 & 26 \\
\hline \multirow[t]{2}{*}{$9 A-36$} & A & 0.31 & 0.62 & 0.62 & 77 \\
\hline & B & 1.18 & 2.55 & 0.49 & 23 \\
\hline $9 A-38$ & A & 0.35 & 0.63 & 0.66 & 75 \\
\hline & B & 1.14 & 2.63 & 0.42 & 25 \\
\hline $9 A-42$ & A & 0.34 & 0.64 & 0.50 & 70 \\
\hline & B & 1.14 & 2.66 & 0.40 & 30 \\
\hline $9 B-12$ & A & 0.32 & 0.61 & 0.34 & 66 \\
\hline & B & 1.12 & 2.68 & 0.36 & 12 \\
\hline & C & 1.23 & 1.86 & 0.33 & 22 \\
\hline $9 B-17$ & A & 0.30 & 0.60 & 0.27 & 55 \\
\hline & C & 1.25 & 1.85 & 0.30 & 45 \\
\hline $9 B-17^{b}$ & A & 0.39 & 0.63 & 0.41 & 50 \\
\hline & C & 1.38 & 2.13 & 0.42 & 50 \\
\hline 9B-20-7 & A & 0.32 & 0.63 & 0.34 & 69 \\
\hline & B & 1.12 & 2.71 & 0.30 & 12 \\
\hline & C & 1.24 & 1.93 & 0.44 & 19 \\
\hline $9 B-20-7^{b, d}$ & A & 0.43 & 0.60 & 0.44 & 66 \\
\hline & $B+C$ & 1.25 & 2.76 & 0.55 & 34 \\
\hline $9 B-24$ & A & 0.33 & 0.63 & 0.48 & 66 \\
\hline & B & 1.13 & 2.62 & 0.43 & 34 \\
\hline 9B-29 & A & 0.36 & 0.73 & 0.51 & 79 \\
\hline & B & 1.13 & 2.68 & 0.30 & 21 \\
\hline $9 B-41$ & A & 0.32 & 0.64 & 0.31 & 100 \\
\hline $9 B-49$ & A & 0.33 & 0.61 & 0.45 & 75 \\
\hline & B & 1.14 & 2.62 & 0.41 & 25 \\
\hline $9 B-53$ & A & 0.32 & 0.61 & 0.35 & 70 \\
\hline & B & 1.13 & 2.62 & 0.37 & 30 \\
\hline 9B-61 & A & 0.33 & 0.64 & 0.34 & 74 \\
\hline & B & 1.15 & 2.68 & 0.35 & 26 \\
\hline
\end{tabular}

a Relative to metallic iron.

${ }^{b}$ Measured at $78 \mathrm{~K}$.

'Two quadrupole doublets were assumed in the fitting calculation of the Mössbauer parameters despite a poor fit (Fig. 2C) because the fit with three quadrupole doublets was not successful.

${ }^{\mathrm{d}}$ Due to poorer statistics at $78 \mathrm{~K}$, doublets B and C could not be resolved. sediments (Samples 9A-22, 9A-27, 9A-42, and 9B-17) are extraordinarily high for oceanic sediments (Table 5). We can estimate the iron distribution in rhodochrosite and other iron-bearing phases in the sediments from the manganese and iron contents in the samples, assuming that all of the manganese is contained in rhodochrosite. Table 5 lists the fraction of iron in rhodochrosite relative to total iron in a sample, assuming that iron substitutes for $2 \%$ of manganese in the rhodochrosite. This estimate indicates that less than $10 \%$ of the total iron in the bulk sediments (except for Sample 9A-27) is contained in the rhodochrosite. The sample with calcite (Sample 9A-9) does not show the absorption (doublet $\mathrm{C}$ ) corresponding to $\mathrm{Fe}^{2+}$ in the calcite lattice (Table 5 and Fig. 4). Furthermore, the iron content in the calcite from Site 799 is very low (Matsumoto, this volume); these results suggest that there is a negligible contribution of calcite to the iron distribution in the sediment. The chemical composition of Sample 9A-27 suggests that considerable amounts of $\mathrm{Fe}^{2+}$ is contained in rhodochrosite (Table 5). This implies that the absorption for rhodochrosite can be seen in the Mössbauer spectrum. Although the fitting assuming three quadrupole doublets was not successful, a small shoulder corresponding to carbonate minerals appears in an envelope of doublet B at a higher velocity (Fig. 2C). The shoulder may indicate a trace of $\mathrm{Fe}^{2+}$ in the rhodochrosite. The spectrum for Sample 9B-17 included the $\mathrm{Fe}^{2+}$ components (doublet $\mathrm{C}$ ), presumably ferroan magnesite (Table 5). As about $7 \%$ of total iron in the bulk sample may be contained in the rhodochrosite (Table 5), the doublet $\mathrm{C}$ for Sample 9B-17 can partly be ascribed to the rhodochrosite.

\section{Depth Profiles of Iron Species in the Sediment Sequences}

Depth profiles of relative contents of iron-species corresponding to doublets $\mathrm{A}, \mathrm{B}$, and $\mathrm{C}$, assuming an equal recoilless fraction, are shown in Figures 7A and 7B for Sites 798 and 799, respectively. It should be pointed out that the determination was carried out without decomposition of the samples. In conventional wet-chemical methods, the $\mathrm{Fe}^{2+}$ content can be determined with oxidation-reduction titration after dissolution. If organic substances are present in the sample, the consumption of the oxidant used

Table 3. Mössbauer parameters for carbonate concretion samples from Sites 798 and 799 from the spectra recorded at $293 \mathrm{~K}$.

\begin{tabular}{lcccc}
\hline $\begin{array}{l}\text { Sample } \\
\text { no. }\end{array}$ & $\begin{array}{c}\text { Isomer } \\
\text { shift }^{\mathrm{a}} \\
(\mathrm{mm} / \mathrm{s})\end{array}$ & $\begin{array}{c}\text { Quadrupole } \\
\text { splitting } \\
(\mathrm{mm} / \mathrm{s})\end{array}$ & $\begin{array}{c}\text { Line } \\
\text { width } \\
(\mathrm{mm} / \mathrm{s})\end{array}$ & $\begin{array}{c}\text { Relative } \\
\text { area } \\
(\%)\end{array}$ \\
\hline $\begin{array}{l}\text { 8A-17 } \\
\text { (ankerite) }\end{array}$ & 0.24 & 0.56 & 0.30 & 18 \\
$\begin{array}{l}\text { 9A-17 } \\
\text { (rhodochrosite) }\end{array}$ & 1.26 & 1.67 & 0.44 & 82 \\
9B-20-2 & 0.36 & 0.63 & 0.51 & 72 \\
(ferroan magnesite) & 1.12 & 2.58 & 0.44 & 28 \\
& 1.23 & 1.84 & 0.33 & 100 \\
$\begin{array}{l}\text { 9B-20-6 } \\
\text { (ferroan magnesite) }\end{array}$ & 1.24 & 1.85 & 0.31 & 77 \\
$\begin{array}{l}\text { 9B-31 } \\
\text { (dolomite) }\end{array}$ & 0.29 & 0.55 & 0.33 & 59 \\
$\begin{array}{l}\text { 9B-48 } \\
\text { (dolomite) }\end{array}$ & 1.36 & 1.36 & 0.72 & 41 \\
\hline
\end{tabular}

${ }^{a}$ Relative to metallic iron. 


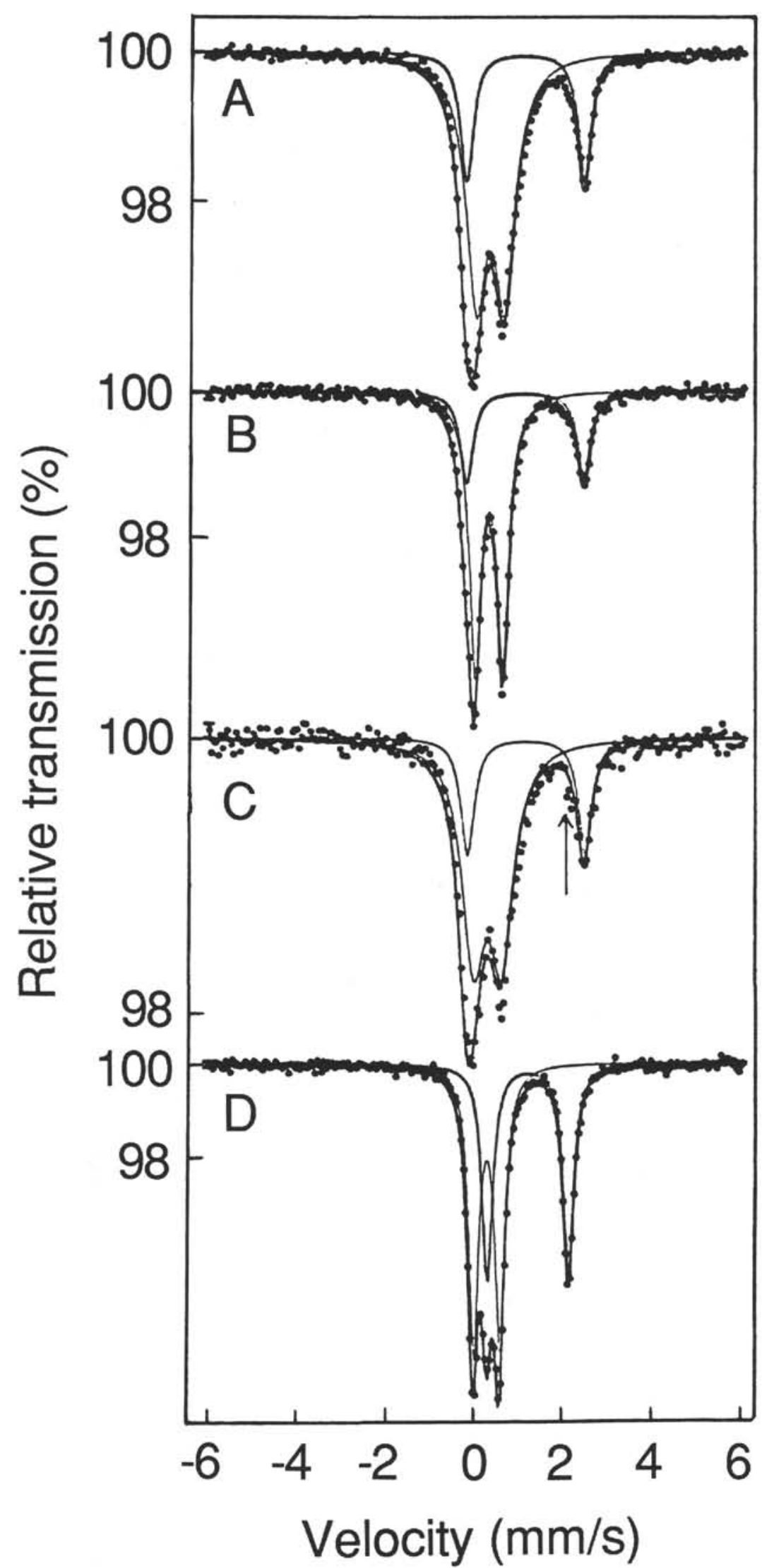

Figure 2. Typical Mössbauer spectra (256 channels after folding) at $293 \mathrm{~K}$ for sediments from Leg 128: Samples 9A-30 (A), 61 (B), 9A-27 (C), and 9B-17 (D). Samples 9A-2 to 9B-17 contain carbonates (Table 1A). The arrow in the spectrum (C) for Sample 9A-27 indicates a trace of carbonate $\mathrm{Fe}^{2+}$ component (see text). 
Table 4. Mössbauer parameters at $293 \mathrm{~K}$ for six sediment samples from Sites 798 and 799 after partial dissolution with citric acid.

\begin{tabular}{|c|c|c|c|c|c|c|}
\hline $\begin{array}{l}\text { Sample } \\
\text { no. }\end{array}$ & $\begin{array}{c}\text { Doublet } \\
\text { component }\end{array}$ & $\begin{array}{c}\text { Isomer } \\
\text { shift" } \\
(\mathrm{mm} / \mathrm{s})\end{array}$ & $\begin{array}{c}\text { Quadrupole } \\
\text { splitting } \\
\text { (mm/s) }\end{array}$ & $\begin{array}{c}\text { Line } \\
\text { width } \\
(\mathrm{mm} / \mathrm{s})\end{array}$ & $\begin{array}{c}\text { Relative } \\
\text { area } \\
(\%) \\
\text { After } \\
\text { Dissolution }\end{array}$ & $\begin{array}{c}\text { Relative } \\
\text { area } \\
(\%) \\
\text { Before } \\
\text { Dissolution }\end{array}$ \\
\hline \multirow[t]{2}{*}{$8 B-47$} & A & 0.33 & 0.60 & 0.52 & 86 & 88 \\
\hline & B & 1.13 & 2.67 & 0.43 & 14 & 12 \\
\hline \multirow[t]{2}{*}{$9 A-6$} & A & 0.34 & 0.57 & 0.51 & 72 & 70 \\
\hline & B & 1.14 & 2.62 & 0.41 & 28 & 30 \\
\hline \multirow[t]{3}{*}{$9 B-12$} & A & 0.32 & 0.56 & 0.39 & 85 & 66 \\
\hline & B & 1.14 & 2.62 & 0.41 & 15 & 12 \\
\hline & C & - & - & - & 0 & 22 \\
\hline \multirow[t]{2}{*}{$9 B-17$} & A & 0.30 & 0.59 & 0.32 & 65 & 55 \\
\hline & C & 1.24 & 1.86 & 0.32 & 35 & 45 \\
\hline \multirow[t]{3}{*}{$9 B-20-7$} & A & 0.31 & 0.60 & 0.47 & 87 & 69 \\
\hline & B & 1.17 & 2.69 & 0.34 & 9 & 12 \\
\hline & C & 1.28 & 1.94 & 0.35 & 4 & 19 \\
\hline $9 \mathrm{~B}-41$ & A & 0.31 & 0.62 & 0.37 & 100 & 100 \\
\hline
\end{tabular}

"Relative to metallic iron.

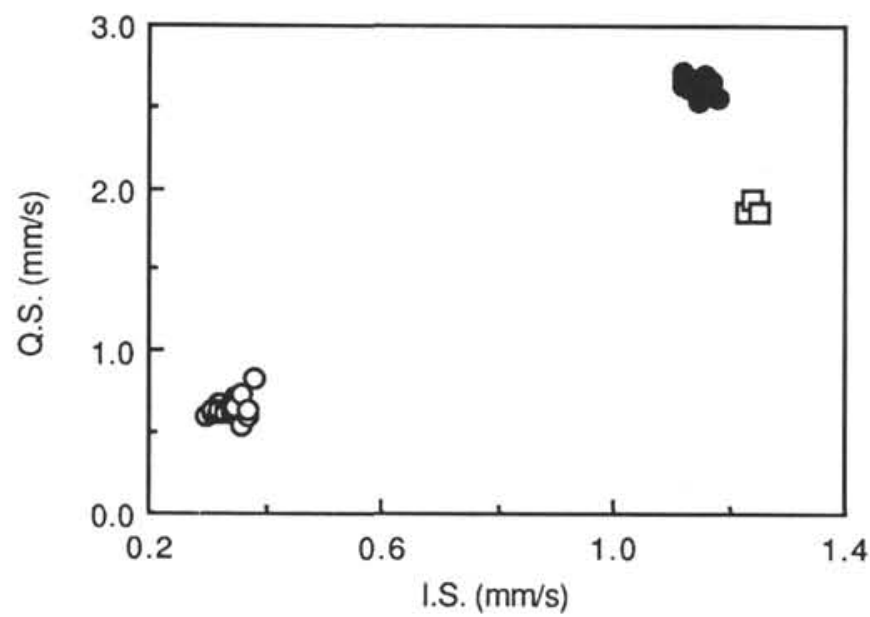

Figure 3. Isomer shift (I.S.) and quadrupole splitting (Q.S.) (Table 2) determined from the Mössbauer spectra at $293 \mathrm{~K}$ on sediments from Sites 798 and 799. Doublet A (open circle), doublet B (solid circle), doublet C (open square).

in titration by organic matter introduces errors in determination of $\mathrm{Fe}^{2+}$. Because Mössbauer spectroscopy is a non-destructive technique, it removes such an uncertainty. At Site 798 (Fig. 7A) the amount of silicate $\mathrm{Fe}^{2+}$ for doublet $\mathrm{B}$ decreases with depth in a regular manner. Such depth profile may indicate a gradual oxidation of $\mathrm{Fe}^{2+}$ in the sediment column.

The depth profile for Site 799 is shown in Figure 7B. The open circles represent the sediment samples containing carbonates. The relative contents of silicate $\mathrm{Fe}^{2+}$ in the uppermost four samples (Samples 9A-1A to 9A-1D) range from $25 \%$ to $28 \%$ in total iron. The percentage of silicate $\mathrm{Fe}^{2+}$ for Sample 9A-1A from the reddish brown layer is not different from that of the Samples 9A-1B to 9A-1D taken from the olive-gray layers at the top of the sediment sequence. The oxidation state of iron and the color have both been used to estimate the oxidation-reduction condition of the sediments (Lyle, 1983). However, the present Mössbauer results suggest that the color of the sediment does not always correlate with silicate $\mathrm{Fe}^{2+}$ percentage.

The relative contents of silicate $\mathrm{Fe}^{2+}$ in the sediments in Unit I (Samples 9A-1A to 9A-6) range from $25 \%$ to $30 \%$ except for the calcite-bearing Sample 9A-9, which shows a lower value (shown as an
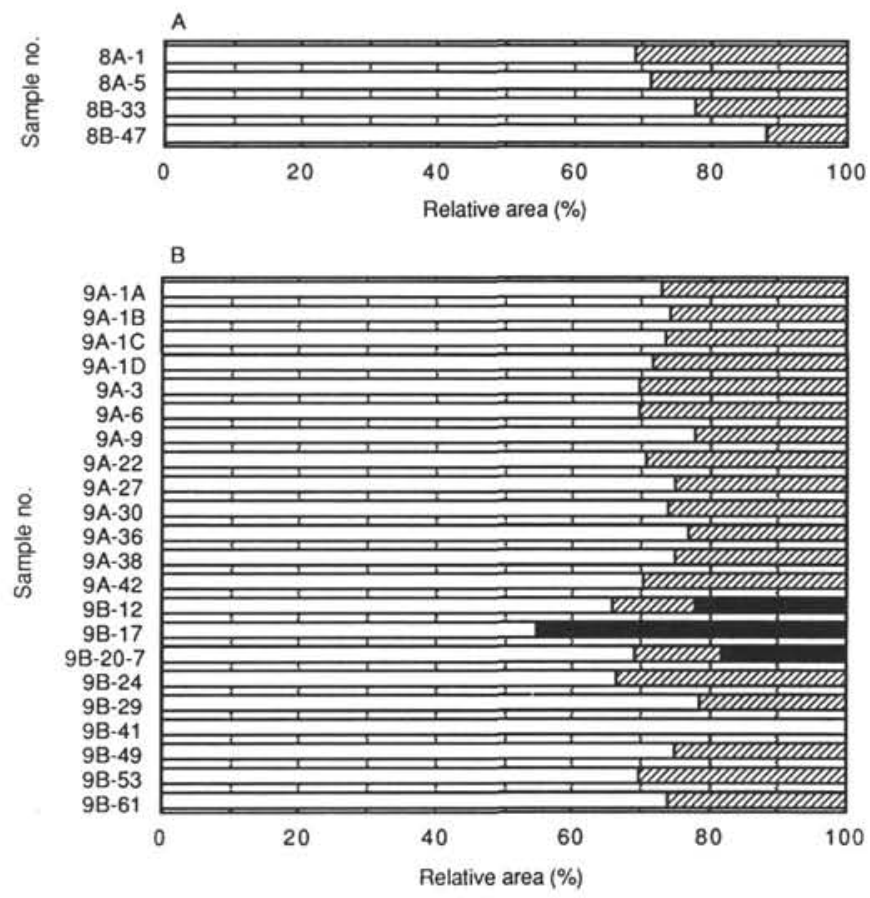

Figure 4. Relative absorption areas for doublets A, B, and C in the spectra of the sediments from Sites 798 (A) and 799 (B). Doublet A (open bar), doublet B (bar with hatching), doublet C (solid bar).

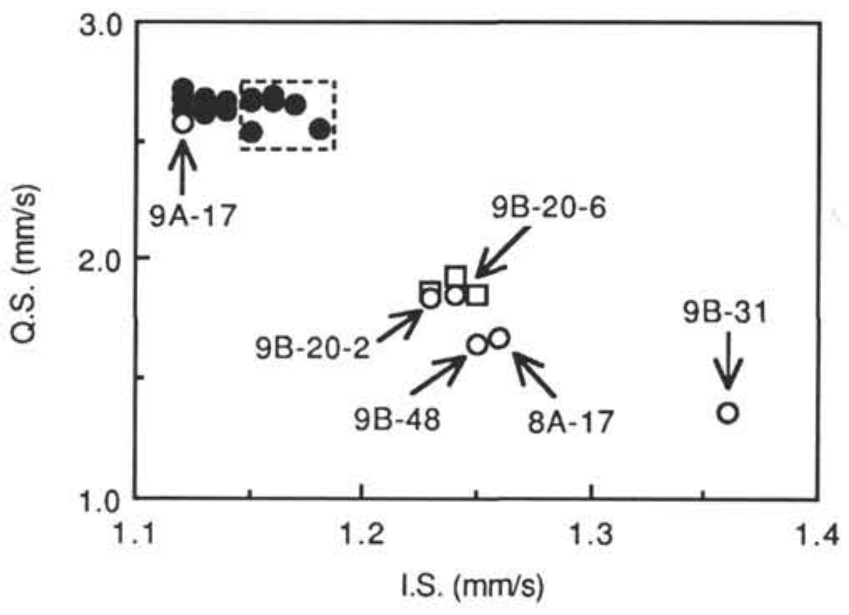

Figure 5. Isomer shift and quadrupole splitting (Table 3) determined from the Mössbauer spectra at $293 \mathrm{~K}$ on carbonate concretion samples from Sites 798 and 799. The high-spin $\mathrm{Fe}^{2+}$-component for the carbonate concretion samples is shown by an open circle. The parameters of doublets B (solid circle) and C (open square) for sediment samples are also plotted for comparison (Table 2). The parameters of doublet Samples 8B-33, 9A-1A, 9A-9, 9A-22, 9A-27, 9A-30, and 9A-36 are enclosed within the broken lines (see text).

open circle in Fig. 7B). In Unit II (Samples 9A-22 to 9A-42), the silicate $\mathrm{Fe}^{2+}$ contents of the sediments range from $23 \%$ to $30 \%$. Rhodochrosite is contained in three samples (Samples 9A-22, 9A-27, and 9A-42, shown as open circles in Fig. 7B); however, it is not considered a major iron-bearing mineral in these sediments (except for Sample $9 \mathrm{~A}-27$, previously mentioned) as no doublet $\mathrm{C}$ is seen in the spectra (Figs. 4 and $7 \mathrm{~B}$ ). The silicate $\mathrm{Fe}^{2+}$ contents were identical to those in the sediments from Unit I. In Unit III (Samples 9B-12 to 9B-29) the silicate $\mathrm{Fe}^{2+}$ contents range from 0\% to 34\%. Except for Sample 9B-24 (667.94 $\mathrm{mbsf}$ ), these values (doublet B) are lower than in the sediments from Units 
A
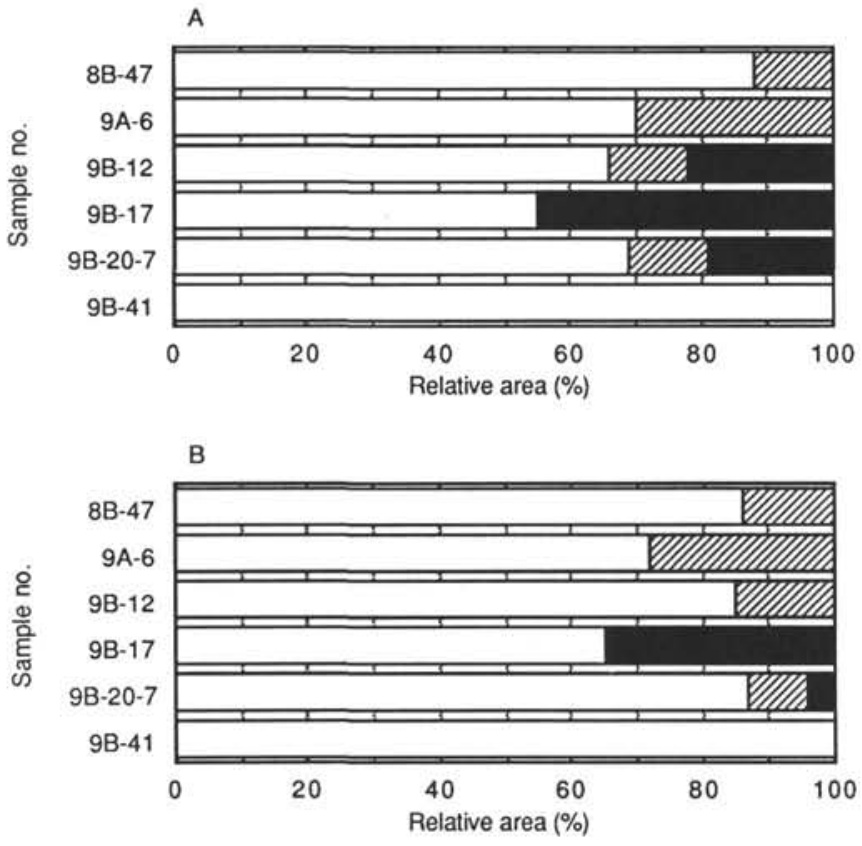

Figure 6. Relative absorption areas for doublets A, B, and C in the spectra of the sediments before (A) and after (B) partial dissolution. Doublet A (open bar), doublet B (bar with hatching), doublet C (solid bar).

Table 5. Relative absorption areas of doublets A, B, and C at 293 $\mathrm{K}$, manganese and total iron colntents, and fraction of iron in rhodochrosite relative to total iron in sediment samples containing carbonates.

\begin{tabular}{lcccccc}
\hline \multicolumn{7}{c}{$\begin{array}{c}\text { Relative area } \\
(\%)\end{array}$} \\
$\begin{array}{l}\text { Sample } \\
\text { no. }\end{array}$ & A & $\begin{array}{c}\text { Doublet } \\
\text { B }\end{array}$ & $\mathrm{C}$ & $\begin{array}{c}\mathrm{MnO}^{\mathrm{a}} \\
(\%)\end{array}$ & $\begin{array}{c}\mathrm{Fe}_{2} \mathrm{O}_{3}{ }^{\mathrm{a}} \text {, b } \\
(\%)\end{array}$ & $\begin{array}{c}\text { Fraction of iron in } \\
\text { rhodochrosite }(\%)^{\mathrm{c}}\end{array}$ \\
\hline $9 \mathrm{~A}-9$ & 78 & 22 & - & 0.07 & 2.51 & 0.0 \\
$9 \mathrm{~A}-22$ & 71 & 29 & - & 5.80 & 5.02 & 2.6 \\
$9 \mathrm{~A}-27$ & 75 & 25 & - & 13.19 & 2.24 & 13.4 \\
$9 \mathrm{~A}-42$ & 70 & 30 & - & 6.17 & 4.60 & 3.0 \\
$9 \mathrm{~B}-17$ & 55 & - & 45 & 18.03 & 6.20 & 6.6 \\
\hline
\end{tabular}

aFrom Minai et al., (this volume).

'Total iron.

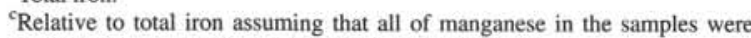
contained in rhodochrosite ( $2 \%$ substitution with iron).

I and II. The $\mathrm{Fe}^{2+}$ component (doublet $\mathrm{C}$ ) ascribed to carbonates (presumably, ferroan magnesite) was observed in the spectra of the three samples from Unit III (Samples 9B-12, 9B-17, and 9B-20-7). In Units IV and V (Samples B-41 to 9B-61) the silicate $\mathrm{Fe}^{2+}$ contents are similar to those in the sediments from Units I and II except for the content in Sample 9B-41, where there is no $\mathrm{Fe}^{2+}$. Although variations of iron species with depth are extremely complicated throughout the sediment sequence at this site; the silicate $\mathrm{Fe}^{2+}$ contents in Unit III tend to be lower than the contents in the other samples (Fig. 7B) with the exception of Sample 9B-41 in Unit IV, where the silicate $\mathrm{Fe}^{2+}$ component was not detected. Note that the carbonate-bearing samples (Samples 9B-12, 9B-17, and 9B-20-7, presumably, ferroan magnesite) show lower values of silicate $\mathrm{Fe}^{2+}$. However, the silicate $\mathrm{Fe}^{2+}$ contents of the sediments with rhodochrosite (Samples 9A-22,9A-27, and $9 \mathrm{~A}-42$ ) are not as low as those of the sediments with ferroan magnesite (Samples 9B-12, 9B-17, and 9B-20-7).

The authigenic formation of iron-bearing carbonates in the sediments relies on a supply of iron to the pore water. Iron is deposited into the sediment as terrigenous detritus and hydrogenous precipi-
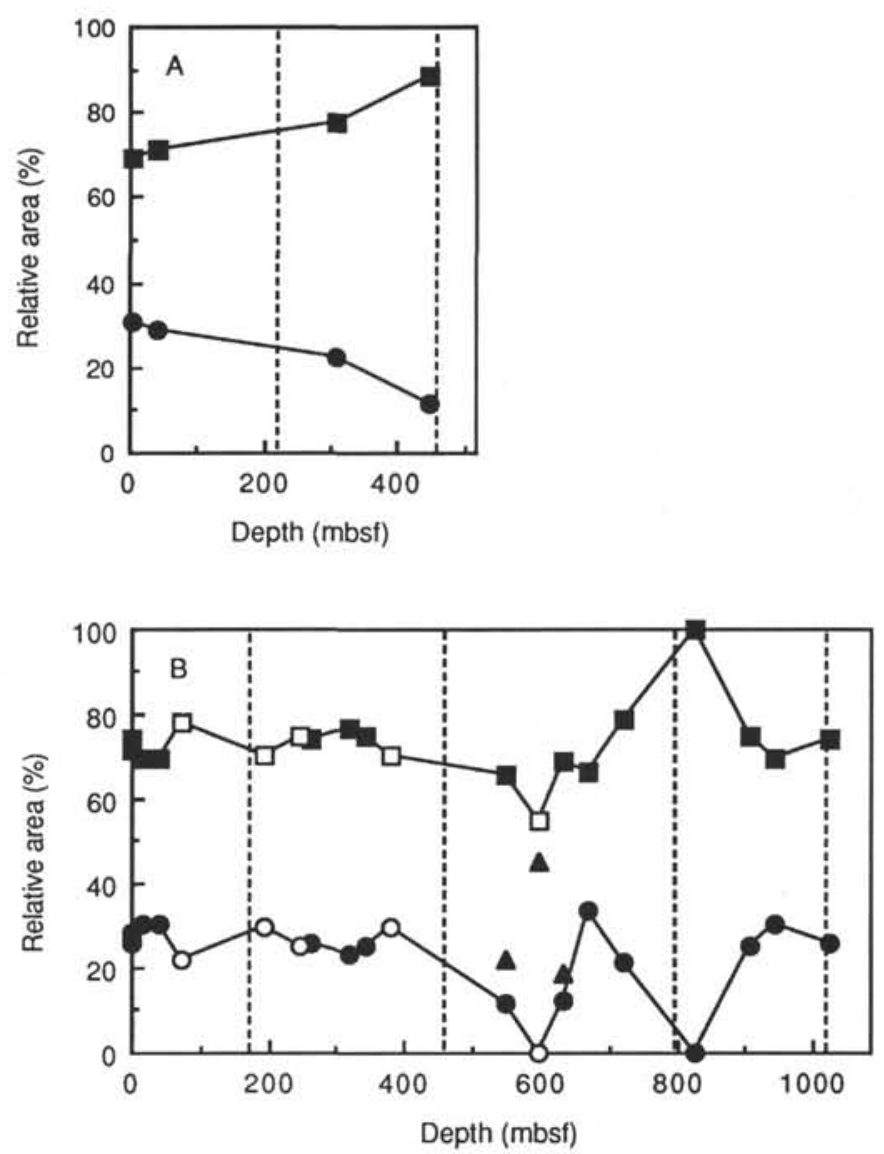

Figure 7. Depth profiles of the relative contents of iron species, corresponding to doublets A (solid and open squares), B (solid and open circles), and C (solid triangles), in sediment samples from Sites 798 (A) and 799 (B). Open squares and circles indicate the relative contents of the iron components for doublets $\mathrm{A}$ and $\mathrm{B}$ in the sediments containing carbonates. Solid squares and circles indicate the relative contents of the iron components for doublets $\mathrm{A}$ and $\mathrm{B}$ in sediments where the carbonates were not explicitly identified. The broken lines indicate the boundaries between the lithologic units.

tates. Because most of iron in terrigenous detritus is contained in aluminosilicate phases, the depth profile of the $\mathrm{Fe}^{2+}$ component ascribed to these minerals (doublet $\mathrm{B}$ ) may indicate a variation in the amount of terrigenous detritus through sedimentation. Alteration of terrigenous minerals during diagenesis can also affect the distribution of the iron species in the sediment sequence. As has been shown by Mössbauer studies on alteration of volcanic rocks (Minai et al., 1978, 1979), $\mathrm{Fe}^{2+}$ in aluminosilicates tends to be oxidized to $\mathrm{Fe}^{3+}$ during formation of clay minerals, ferric gel, hydroxides, and oxyhydroxides. Also, a fraction of the silicate $\mathrm{Fe}^{2+}$ in the sediments is possibly lost by the formation of ferric components during low-temperature diagenesis. In any case, hydrogenous precipitation and diagenetic alteration of aluminosilicates can both contribute to the amount of the ferric minerals. A lower percentage of the silicate $\mathrm{Fe}^{2+}$ component indicates a larger amount of hydrogenous precipitates and an increase in authigenic ferric minerals formed during diagenesis. As seen in Figure 7B, the carbonate $\mathrm{Fe}^{2+}$ (doublet $\mathrm{C}$ ) changes inversely with the silicate $\mathrm{Fe}^{2+}$ content (doublet $\mathrm{B}$ ) in Unit III, indicating that terrigenous iron is less abundant in sediment samples that contain ferroan magnesite. Sample 9B-41, in which no silicate $\mathrm{Fe}^{2+}$ was observed in the spectrum, contains abundant pyrite. Pyrite is an authigenic mineral formed in reductive conditions. The relative amounts of hydrogenous and terrigenous iron supplied to the sediment may be a factor for the 
formation of various carbonate minerals and pyrite in the sediment column. Nondestructive Mössbauer determination of $\mathrm{Fe}^{2+}$ content in silicates and carbonates provides a clue to unraveling the conditions of sedimentation and diagenetic processes in marine sediments.

\section{SUMMARY}

The Mössbauer spectra for sediments from Sites 798 and 799 were deconvolved to one to three pairs of quadrupole doublets ascribed to high-spin $\mathrm{Fe}^{2+}$ and paramagnetic $\mathrm{Fe}^{3+}$ (partly, pyrite). The $\mathrm{Fe}^{2+}$ absorptions are attributed to $\mathrm{Fe}^{2+}$ in aluminosilicates and carbonates. Comparison of the Mössbauer spectra for the sediments with the spectra for the carbonate concretions indicates that the $\mathrm{Fe}^{2+}$-bearing carbonates in the sediments analyzed are presumably ferroan magnesite. The depth profiles of iron components suggest that the relative amounts of hydrogenous and terrigenous iron may be related to the formation of different carbonate phases.

\section{ACKNOWLEDGMENTS}

The authors thank the reviewers for their critical comments and recommendations, which were very valuable for improving the manuscript.

\section{REFERENCES}

Bancroft, G. M., 1973. Mössbauer Spectroscopy: An Introduction for Inorganic Chemists and Geochemists: London (McGraw-Hill).

Bancroft, G. M., Burns, R. G., and Stone, A. J., 1968. Applications of the Mössbauer effect to silicate mineralogy-II. Iron silicates of unknown and complex crystal structures. Geochim. Cosmochim. Acta, 32:547-559.

Bancroft, G. M., Maddock, A. G., and Burns, R. G., 1967. Applications of the Mössbauer effect to silicate mineralogy-I. Iron silicates of known crystal structure. Geochim. Cosmochim. Acta, 31:2219-2246.

Bowen, L. H., and Weed, S. B., 1984. Mössbauer spectroscopy of soils and sediments. In Herber, R. H. (Ed.), Chemical Mössbauer Spectroscopy: New York (Plenum), 217-242.

Duke, B. J., and Gibb, T. C., 1967. Numerical estimation of Mössbauer parameters. J. Chem. Soc., A:1478-1483.
Greenwood, N. N., and Gibb, T. C., 1971. Mössbauer Spectroscopy: London (Chapman and Hall).

Herzenberg, C. L., 1970. Mössbauer spectrometry as an instrumental technique for determinative mineralogy. In Gruverman, I. J. (Ed.), Mössbauer Effect Methodology (Vol. 5): New York (Plenum), 209-230.

Ingle, J. C., Jr., Suyehiro, K., von Breymann, M. T., et al., 1990. Proc. ODP, Init. Repts., 128: College Station, TX (Ocean Drilling Program).

Lyle, M., 1983. The brown-green color transition in marine sediments: a marker of the $\mathrm{Fe}(\mathrm{III})-\mathrm{Fe}(\mathrm{II})$ redox boundary. Limnol. Oceanogr., 28:1026-1033.

Minai, Y., Furuta, Y., Kobayashi, K., and Tominaga, T., 1981. A Mössbauer study of deep sea sediments. Radiochem. Radioanal. Lett., 48:165-174.

Minai, Y., Nakamura, Y., and Tominaga, T., 1987. A Mössbauer study of oceanic sediments from Site 612, Deep Sea Drilling Project Leg 95. In Poag, C. W., Watts, A. B., et al., Init. Repts. DSDP, 95: Washington (U.S. Govt. Printing Office), 641-645.

Minai, Y., Takeda, M., Wakita, H., and Tominaga, T., 1978. A Mössbauer study on alteration of a deep sea basalt. Radiochem. Radioanal. Lett., 36:199-206. , 1979. Study on alteration of a continental (flood) basalt by Fe-57 Mössbauer technique. Radiochem. Radioanal. Lett., 39:279-286.

Minai, Y., and Tominaga, T., 1982. Mössbauer analysis of iron(II) and iron(III) in geological reference materials. Int. J. Appl. Radiat. Isotopes, 33:513-515.

Morice, J. A., Rees, LV.C., and Rickard, D. T., 1969. Mössbauer studies of iron sulphides. J. Inorg. Nucl. Chem., 31:3797-3802.

Mørup, S., Franck, J., van Wonterghem., J., Roy-Poulsen, H., and Larson, L., 1985. Mössbauer spectroscopy study of the chemical state of iron in Danish Mesozoic sediments. Fuel, 64:528-539.

Ono, K., and Ito, A., 1964. Mössbauer study of magnetic properties in ferrous compounds. J. Phys. Soc. Jpn., 19:899-907.

Thijs, A., De Roy, G., Vansant, E. F., Glasby, G. P., and Thijssen, T., 1981. Mössbauer effect studies of iron in manganese nodules and associated marine sediments in five areas in the equatorial and S. W. Pacific. Geochem. J., 15:25-37.

Tominaga, T., and Minai, Y., 1984. Applications of Mössbauer spectroscopy to environmental and geochemical studies. Nucl. Sci. Appl., 1:749-791.

Date of initial receipt: 18 March 1991

Date of acceptance: 13 December 1991

Ms 127/128B-181 